This article was downloaded by: [University of Oxford]

On: 11 August 2008

Access details: Access Details: [subscription number 731915744]

Publisher Routledge

Informa Ltd Registered in England and Wales Registered Number: 1072954 Registered office: Mortimer House, 37-41 Mortimer Street, London W1T 3JH, UK

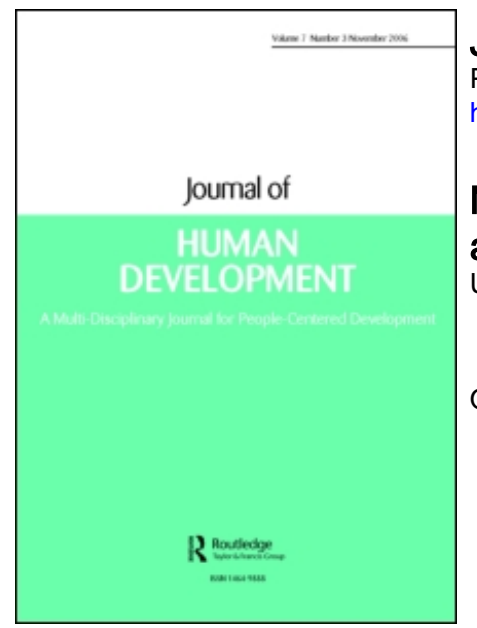

\title{
Journal of Human Development
}

Publication details, including instructions for authors and subscription information:

http://www.informaworld.com/smpp/title content=t713431425

\section{Multidimensional Poverty Measurement with Economic Well-being, Capability, and Social Inclusion: A Case from Kathmandu, Nepal \\ Udaya Wagle}

Online Publication Date: 01 November 2005

To cite this Article Wagle, Udaya(2005)'Multidimensional Poverty Measurement with Economic Well-being, Capability, and Social Inclusion: A Case from Kathmandu, Nepal',Journal of Human Development,6:3,301 - 328

To link to this Article: DOI: $10.1080 / 14649880500287621$

URL: http://dx.doi.org/10.1080/14649880500287621

\section{PLEASE SCROLL DOWN FOR ARTICLE}

\footnotetext{
Full terms and conditions of use: http://www.informaworld.com/terms-and-conditions-of-access.pdf

This article may be used for research, teaching and private study purposes. Any substantial or systematic reproduction, re-distribution, re-selling, loan or sub-licensing, systematic supply or distribution in any form to anyone is expressly forbidden.

The publisher does not give any warranty express or implied or make any representation that the contents will be complete or accurate or up to date. The accuracy of any instructions, formulae and drug doses should be independently verified with primary sources. The publisher shall not be liable for any loss, actions, claims, proceedings, demand or costs or damages whatsoever or howsoever caused arising directly or indirectly in connection with or arising out of the use of this material.
} 


\title{
Multidimensional Poverty Measurement with Economic Well-being, Capability, and Social Inclusion: A Case from Kathmandu, Nepal
}

\author{
UDAYA WAGLE \\ Udaya Wagle is Assistant Professor at the School of Public Affairs, Western \\ Michigan University, Kalamazoo, USA
}

\begin{abstract}
The contemporary, income and consumption approaches to poverty definition and measurement, which are unidimensional in nature, are unable to capture multiple dimensions of poverty. The multidimensional approach operationalized here in the structural equation framework suggests that the multidimensionality of poverty hypothesis holds for the population in Kathmandu, Nepal, including economic well-being, capability, and social inclusion. While all of these dimensions are integral, the capability dimension appears to be highly influential, affecting every other poverty dimension. This paper identifies indicators appropriate to measure different poverty dimensions and, although the multidimensional approach necessitates further work for more simplified and policy relevant application, alternative ways are explored with their practical implications.
\end{abstract}

Key words: Economic well-being, Capability, Economic inclusion, Political inclusion, Civic/cultural inclusion, Structural equation modeling, Kathmandu, Nepal, Asia

\section{Introduction}

Historically, poverty research has been dominated by the notion of economic well-being, and with it studies of income and consumption. Equating poverty to one's inability to acquire a level of income that is adequate to maintain basic living standards (Citro and Michael, 1995; MacPherson and Silburn, 1998), income and consumption have been used widely as its proxy measures. While there have been attempts to define and determine monetary estimates of basic living standards (Orshansky, 1965; International Labour Organization, 1976; Rowntree, 1901), they have broached controversies over basic assumptions of what constitutes basic 
living standard and what consumption - or non-consumption - items it should include.

More recent developments emphasize capability and social exclusion - or social inclusion, to be more positive - as alternative and more promising approaches to poverty analysis. First, linking poverty with the broader concepts of freedom and human rights, the capability approach suggests that poverty and well-being are functions of capabilities. Drawing on the works of Amartya Sen $(1987,1992,1999)$, this capability notion postulates that poverty results from a lack of capability to 'function' or to 'achieve' well-being, where well-being is defined as the "ends" and capability as the "means" to achieve it (United Nations Development Programme [UNDP], 2000a,b). With the assumption that improvements in anthropometric measures are possible only with individual capabilities, proponents of the capability approach argue that education, health, and ethnic and gender disparities - while broader societal and structural forces help determine them - indicate one's status of poverty and human well-being (Muellbauer, 1987; Sen, 1992).

Second, poverty research has greatly benefited from social inclusion studies, focusing on social processes that inhibit people from acquiring resources needed to avoid poverty (Silver, 1994, 1995; European Foundation, 1995; International Institute of Labour Studies, 1996; Strobel, 1996; Cannan, 1997; de Haan and Maxwell, 1998). While these studies attempt to deal with broader issues of human well-being, findings that social inclusion and poverty greatly reinforce each other have tremendous implications for poverty analysis (Gore et al., 1995; Figueroa et al., 1996; International Institute of Labour Studies, 1996; Gore and Figueiredo, 1997). Following the social inclusion approach, individuals and households can be excluded in three broadly construed dimensions - economic, political, and civic/cultural (Strobel, 1996; Atkinson, 1998; Evans, 1998; Taylor, 1999). An exclusion from economic activities in the labor market, financial resources, and the formal sector economy, for example, can effectively deny one the needed economic opportunities. A lack of participation in political activities such as securing voting rights, voting, partisan activities, and holding political positions is likely to block access to political resources as well as citizenship rights. Furthermore, participation in civic/cultural activities enables one to benefit from extended social networks and ties that are essential, for example, in getting good jobs, securing credits, and sending children to better schools.

Widespread arguments surface for the application of a multidimensional approach to poverty (Ravallion, 1996; Wagle, 2002). While economic well-being, capability, and economic, political, and civic/cultural inclusion are integral parts of a comprehensive, multidimensional concept of poverty, proper operationalization is still lacking (Oyen, 1995; Wagle, 2002). Going beyond limited multidimensionality (Ravallion, 1996; Burchardt et al., 2002; Tsui, 2002; Dewilde, 2004), ${ }^{1}$ this analysis integrates all five major dimensions of poverty in a truly comprehensive framework 
and applies in Kathmandu. Given many alternative ways to actually use the information to derive poverty outcomes, it creates a platform for further discussions on a more refined, policy relevant application of this multidimensional approach.

Following this introduction, this paper presents in the following section the overall policy context in Kathmandu and explains the dataset. Section three poses major questions and hypotheses, while section four develops and estimates the multidimensional model. Section five presents results with their general implications, while the final section concludes with discussions and suggestions for future research.

\section{Context and data set}

Kathmandu Metropolitan City, the geographic focus of this paper, witnessed a thriving economy in the 1990s. The emerging tourism industry and development of the city as a major commercial and administrative center in Nepal, among other things, contributed to an annual income growth of well over $5 \%$, which is much higher than in other parts of the country (UNDP/Nepal, 1998, 2002). Kathmandu represents one of many urban centers in the developing world where increasing urbanization and economic liberalization have not benefited the masses and the incidence of poverty has remained considerably high. Clearly, this has caused an alarm among policy-makers seeking to create a tide to lift all boats.

There is a paucity of studies that examine this complex situation, however. The focus of the extant poverty research, for example, has been on macroeconomic issues (World Bank, 1991; National Planning Commission, 1992; UNDP/Nepal, 1998) or issues concerning some specific population segments (Baker et al., 1997; Weiss, 1999). As elsewhere, more specific studies conducted primarily at the national level have embraced income or consumption approaches (Central Bureau of Statistics, 1997; World Bank, 2003a). Critics question the validity of these approaches that show significant improvement in poverty reduction ${ }^{2}$ at a time in which the nine-year Communist (Maoist) insurgency claiming over 12000 lives has brought all major activities to a standstill, thereby effectively crippling the economy, making all types of elections long overdue, and establishing a complete anarchy in the country.

This study investigates poverty in Kathmandu, using data derived from a random survey of 625 households ${ }^{3}$ conducted in 2002 and 2003. The survey gathered data on a variety of household well-being issues through interviews with householders or other knowledgeable members on households' economic, social, and political dynamics. Sampling involved delineating some 224 geographic clusters out of the 35 city-wards and, with the help of an Arial map, selecting two to four households from each cluster depending on its size and population. A group of eight university students identified the sampled households out of the planned sample of 
672 households and interviewed them, using a standardized survey instrument. In case of failure to interview people from the chosen households, the interviewers interviewed householders from adjacent houses. A number of measures were adopted to maintain validity and reliability of the data including a balanced gender composition of interviewers, appropriate interviewer training, and standardization of both questions asked and the interview process.

The resulting sample data compared reasonably well with the population census data collected in 2001. Sample proportions on sex, age group, religion, region, and type of dwelling, for example, lay within a 6\% margin around the population proportions (Central Bureau of Statistics, 2002; Kathmandu Metropolitan City, 2003). Similarly, the sample average for household size, one of the defining characteristics of population, was just 0.39 greater than the population average. Although the data set was fairly comprehensive, this analysis uses indicators of economic well-being, capability, and social inclusion as and when appropriate. A list of variables is provided in the Appendix, along with their definitions and coding schemes.

\section{Questions and hypotheses}

This paper primarily centers on the definition and measurement of poverty, with immediate focus on whether the operational definition supplied is empirically supported. The operational definition used is that poverty is a relative concern, in which economic well-being, capability, and social inclusion dimensions indicate the overall state of household wellbeing, with those at the bottom of the distribution of each of these dimensions being the poorest of the poor. Because the five dimensions including economic well-being, capability, and three social inclusion dimensions - economic, political, and civic/cultural - are unobservable and because existing research is only indicative of potentially appropriate indicators, the study poses the question of which indicators are appropriate to measure each of the poverty dimensions. The measurement of economic well-being can be straightforward, while the measurements of the capability and three social inclusion dimensions are more complex, thus invoking appropriate empirical guidance.

To test the operational definition provided, the hypothesis presented is that the multidimensionality of poverty holds with statistically significant relationships among the five poverty dimensions and that the relationships among the dimensions are all positive. This would indicate whether all five dimensions are integral to poverty measurement and whether one's high score on one dimension would minimize its probability of being poor overall. Finally, the study seeks to identify an appropriate method to apply the multidimensional approach, necessitating examination of alternative ways the produced dimension scores can be aggregated to identify the poverty status of households. 


\section{The model}

The multidimensional model of poverty attempts to test many poverty theories, based on the conviction that these isolated theories are not mutually exclusive and that integrating them would be highly useful to more realistically measure poverty. Recognizing economic well-being, capability, and economic, political, and civic/cultural inclusion as different dimensions of poverty, this model estimates household scores on each of these dimensions. Because of the involvement of five latent dimensions measurable using instrumental variables, the model is best suited for estimation in the structural equation modeling framework. Structural equation modeling is a statistical technique that employs sample covariance matrix of the observed variables, estimates the population covariance matrix as indicated by the specifications provided, and indicates how well the two matrices match (Bollen, 1989). The following equations apply:

$$
\begin{aligned}
& \eta=B \eta+\zeta \\
& y=\Lambda \eta+\varepsilon
\end{aligned}
$$

where $\boldsymbol{\eta}$ is the vector containing $\eta_{1}, \eta_{2}, \eta_{3}, \eta_{4}$, and $\eta_{5}$ as the estimates of economic well-being, capability, and economic, political, and civic/ cultural inclusion, respectively; ${ }^{4} \boldsymbol{y}$ is the vector of five $\boldsymbol{\eta}$ values; $\zeta$ is the error in equation; $\varepsilon$ is the vector of measurement errors; $\boldsymbol{B}$ is the coefficient matrix; and $\Lambda$ is the vector of factor loadings. The first, latent variable equation specifies the causal relationships among the poverty dimensions whereas the second, the measurement equation, resembling a multivariate regression model, specifies the relationships between poverty dimensions and their indicators. With the integration of factor analysis and multivariate regression, this model requires estimating poverty dimensions using the associated indicators and their interrelationships.

The final model presented in Figure 1, while maintaining the basic framework intact, derives after multiple iterations of specification, estimation, and evaluation. ${ }^{5}$ The use of categorical indicators with highly skewed distributions makes the estimation process more complicated, necessitating computation of 'tetrachoric,' 'polychoric,' and 'polyserial' correlations. Utilizing these correlations, the weighted least-squared estimator used here provides precise estimates, thus making it best suited to handle this complicated estimation environment (Muthen and Muthen, 2001).

As presented in Table 1, the overall goodness-of-fit measures produced by the model lie within a reasonable range. First, while its $\chi^{2}$ statistic of 880 with 182 degrees of freedom does not yield a $p$ value anywhere close to the ideal probability level of at least 0.05 , the ratio of $\chi^{2}$ statistic to the degrees of freedom estimated at 4.84 lies within the liberal comfort zone of less than five (Bollen, 1989). 


\section{U. Wagle}

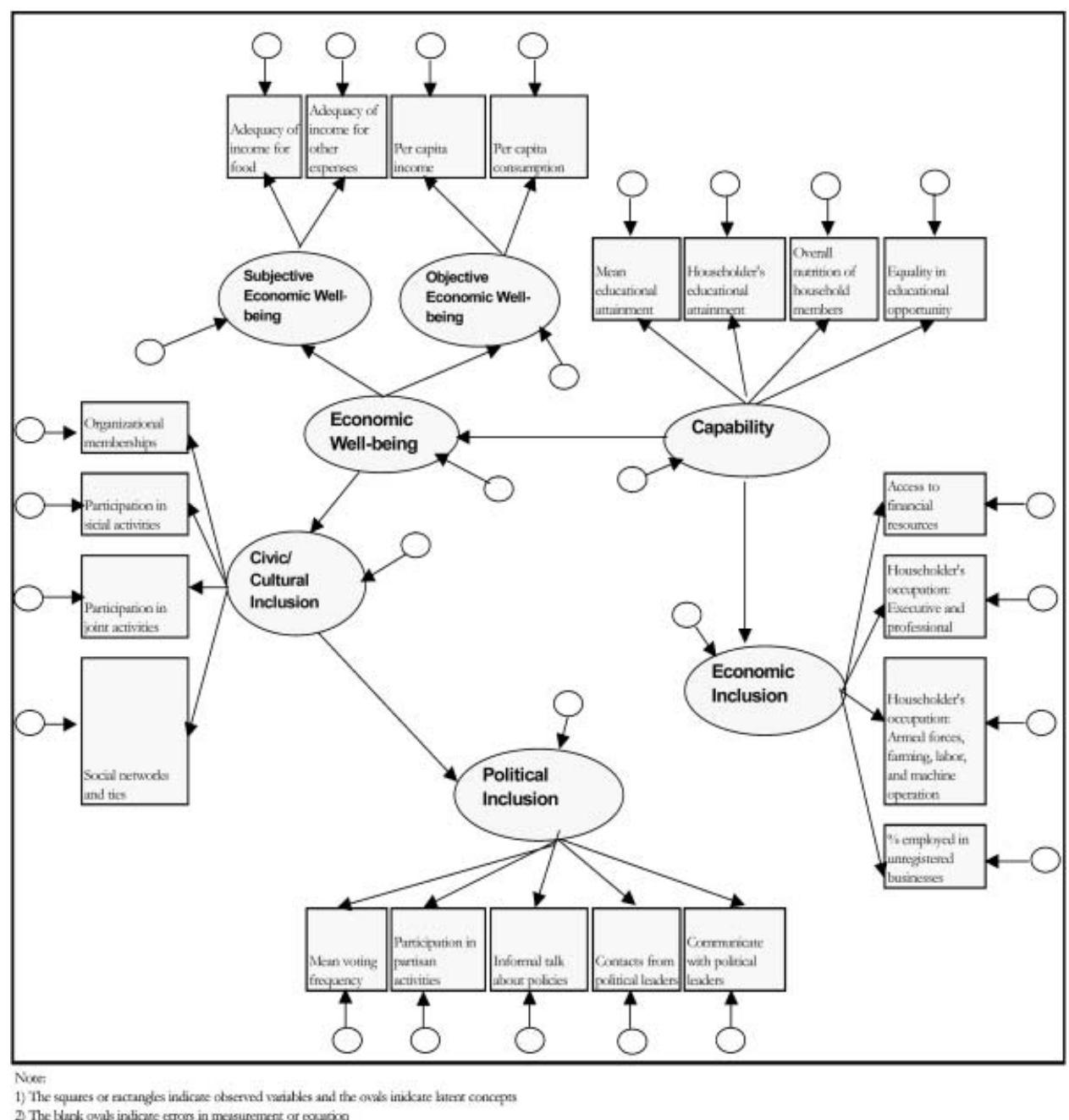

FIGURE 1. The multidimensional poverty model.

This appears to be adequate considering the highly skewed distribution of several indicator variables and the complexity of the model with multiple latent concepts to be estimated. ${ }^{6}$ Other popular fit measures including the root mean squared error approximation, the cumulative fit index, and the Tucker-Louis index reported in Table 1 also indicate that the model demonstrates adequate fit (Bollen, 1989; Garson, 2003). Additionally, the $R^{2}$ estimates provided in Table 2 suggest that the model is capable of explaining relatively high degrees of variation in the observed as well as latent variables. Especially notable are the considerably large $R^{2}$ estimates for almost all poverty dimensions, signifying the strength of the model. 
Table 1. Estimation of the multidimensional poverty model (standard errors in the parenthesis)

\begin{tabular}{|c|c|c|c|c|c|c|c|}
\hline Variable/Dimension & $\begin{array}{l}\text { Subjective Economic } \\
\text { Well-being }\end{array}$ & $\begin{array}{l}\text { Objective Economic } \\
\text { Well-being }\end{array}$ & $\begin{array}{l}\text { Economic } \\
\text { Well-being }\end{array}$ & Capability & $\begin{array}{l}\text { Economic } \\
\text { Inclusion }\end{array}$ & $\begin{array}{l}\text { Political } \\
\text { Inclusion }\end{array}$ & $\begin{array}{l}\text { Civic/Cultural } \\
\text { Inclusion }\end{array}$ \\
\hline \multicolumn{8}{|l|}{ Indicators: } \\
\hline Adequacy of income for food & 1 & & & & & & \\
\hline Adequacy of income for other expenses & $\begin{array}{l}0.971 * * \\
(0.042)\end{array}$ & & & & & & \\
\hline Income per capita & & 1 & & & & & \\
\hline Consumption per capita & & $\begin{array}{l}5.383 * \\
(0.267)\end{array}$ & & & & & \\
\hline Mean educational attainments for adults & & & & 1 & & & \\
\hline Householder's educational attainment & & & & $\begin{array}{l}1.651 * * \\
(0.083)\end{array}$ & & & \\
\hline Equality in educational opportunity & & & & $\begin{array}{l}2.395 * * \\
(0.234)\end{array}$ & & & \\
\hline Overall nutrition of household members & & & & $\begin{array}{l}3.889 * * \\
(0.271)\end{array}$ & & & \\
\hline Access to financial resources & & & & & 1 & & \\
\hline $\begin{array}{l}\text { Householder's occupation: } \\
\text { executive and profesional }\end{array}$ & & & & & $\begin{array}{l}0.614 * * \\
(0.086)\end{array}$ & & \\
\hline \% employed in unregistered businesses & & & & & $\begin{array}{l}-0.793 * * \\
(0.101)\end{array}$ & & \\
\hline $\begin{array}{l}\text { Householder's occupation: Armed forces, } \\
\text { farming, labor, and machine operation }\end{array}$ & & & & & $\begin{array}{l}-1.035 * * \\
(0.095)\end{array}$ & & \\
\hline Mean voting frequency & & & & & & 1 & \\
\hline Participation in partisan activities & & & & & & $\begin{array}{l}0.935 * * \\
(0.162)\end{array}$ & \\
\hline Informal talk about policies & & & & & & $\begin{array}{l}1.403 * * \\
(0.206)\end{array}$ & \\
\hline Contacts from political leaders & & & & & & $\begin{array}{l}0.978 * * \\
(0.147)\end{array}$ & \\
\hline Communication with political leaders & & & & & & $1.54 * *$ & \\
\hline
\end{tabular}


Table 1. (Continued.)

Variable/Dimension

Subjective Economic

Objective Economic

Well-being

Economic

Capability

Economic

Political

Civic/Cultura

Well-being

Well-being

Inclusion

(0.229)

Inclusion

Organizational memberships per capita

Participation in social activities

Participation in joint activities

Social networks and ties

1

$0.487 * *$

(0.056)

$0.703 * *$

(0.062)

$0.304 * *$

(0.055)

Latent Concepts:

Subjective economic well-being

Objective economic well-being

Capability

$0.392 * *$

(0.027)

$3.686 * * \quad 3.319 * *$

(0.265)

(0.236)

Civic/cultural inclusion

Economic well-being 
Table 2. $R^{2}$ estimates

\begin{tabular}{|c|c|}
\hline Indicators/Latent Concepts & Estimate \\
\hline \multicolumn{2}{|l|}{ Indicators: } \\
\hline Adequacy of income for food & 0.721 \\
\hline Income per capita & 0.432 \\
\hline Consumption per capita & 0.857 \\
\hline Adequacy of income for other expenses & 0.68 \\
\hline Mean educational attainments for adults & 0.486 \\
\hline Overall nutrition of household members & 0.496 \\
\hline Householder's educational attainment & 0.374 \\
\hline Equality in educational opportunity & 0.188 \\
\hline Householder's occupation: executive and profesional & 0.183 \\
\hline$\%$ employed in unregistered businesses & 0.142 \\
\hline Householder's occupation: Armed forces, farming, labor, and machine operation & 0.522 \\
\hline Access to financial resources & 0.487 \\
\hline Mean voting frequency & 0.152 \\
\hline Participation in partisan activities & 0.256 \\
\hline Informal talk about policies & 0.577 \\
\hline Contacts from political leaders & 0.28 \\
\hline Communication with political leaders & 0.696 \\
\hline Organizational memberships per capita & 0.135 \\
\hline Participation in social activities & 0.214 \\
\hline Participation in joint activities & 0.445 \\
\hline Social networks and ties & 0.083 \\
\hline \multicolumn{2}{|l|}{ Latent concepts: } \\
\hline Subjective economic well-being & 0.676 \\
\hline Objective economic well-being & 0.422 \\
\hline Economic well-being & 0.914 \\
\hline Economic inclusion & 0.742 \\
\hline Political inclusion & 0.642 \\
\hline Civic/cultural inclusion & 0.391 \\
\hline
\end{tabular}

Note: The model does not report R-squared estimate for the capability dimension as it appears to be an exogenous concept, esitmated without the effect of other latent concepts.

\section{Results}

\section{The indicators of poverty dimensions}

While it is debatable which indicators are best suited to measure the poverty dimensions, I use the model output presented in Table 1 together with the exploratory factor analysis results ${ }^{7}$ (not reported) to identify the appropriateness of the indicators used. First, the potential indicators of economic well-being include income, wealth, consumption, and other subjective views regarding the adequacy of income for food and non-food expenses, and the effect of increase in income on food and non-food expenses (Pradhan and Ravallion, 2000; World Bank, 2001, 2003a; UNDP, 2002). The model overwhelmingly supports that income, consumption, and adequacy of income for food and for non-food expenses are appropriate indicators of economic well-being. Clear cleavages exist, however, between the objective and subjective notions of poverty (Wagle, 2004a). The former is measured through income and consumption, and 
the latter through householders' views on the adequacy of income for food and non-food expenses.

Second, the literature suggests that the indicators of capability may include educational status, health and nutritional status, gender discrimination within households, and ethnic discrimination in neighborhoods (Sen, 1992, 1999; Satterthwaite, 1995; Beall, 1997; Ruel et al., 1999; Checchi and Lucifora, 2000; UNDP, 2000a,b). Results indicate with a high degree of confidence that householder's educational attainment, average educational attainment for adults aged 18 and older, overall nutritional status as revealed by householders, and equality of educational opportunities among both genders in households can be used as indicators of capability.

Third, the potentially relevant indicators of economic inclusion include employment status, occupation, industry of employment, caste and ethnic discrimination in economic activities, and access to financial resources (Khundker et al., 1994; Atkinson, 1998; Evans, 1998; Moser, 1998; Chatterjee, 1999; Castel, 2000). The model suggests that statistically significant indicators include being in executive and professional occupation; being in farm, armed forces, labor, or machine operations occupations; ${ }^{8}$ percentage of members employed in unregistered businesses; and access to financial resources.

Fourth, the theory suggests that political inclusion can be measured employing citizenship card holding, voter registration, participation in political activities, participation in informal policy talks, headship of political positions, visits from politicians, and communication with politicians (Gore et al., 1995; de Wit, 1996; Figueroa et al., 1996; Strobel, 1996; Taylor, 1999; UNDP, 2000a; Burchardt et al., 2002). The model uncovered statistical confidence for five of these indicators. including voting frequency, participation in political activities, participation in informal policy talks, visits from political leaders, and communication with political leaders.

Fifth, the indicators of civic and cultural inclusion may include organizational memberships, participation in social activities, participation in joint activities, family contacts, social networks and ties, access to noneconomic help, and availability of friends for children in the neighborhood (Amis and Rakodi, 1994; Gunatilleke and Perera, 1994; Jordan, 1996; White, 1997; Castel, 2000; Opel, 2000; Burchardt et al., 2002; Grootaert, 2002). The model supports the fact that average organizational memberships for adults, participation in social activities, participation in joint activities, and social networks and ties can be used as indicators of civic/ cultural inclusion with very high confidence.

\section{The multidimensionality of poverty}

Consistent with the operational definition used, the existence of a strong relationship among the five poverty dimensions supports the 
multidimensionality hypothesis, indicating that these dimensions are in fact all embedded in poverty. The model supports that each of the five dimensions has some causal effects on some or all other poverty dimensions (see Table 1 and Fig. 1).

Two sets of statistics are important to address the nature and magnitude of the relationships among poverty dimensions. First, the correlation statistics presented in Table 3 conspicuously suggest that all five dimensions are highly and positively related. This positive relationship is consistent with the multidimensional poverty definition, suggesting that a household's relatively high score on one dimension reduces its overall probability of being poor. The considerably large correlation estimates corroborate that when households are more capable, they tend to have higher levels of economic well-being as well as more meaningful participation in economic activities. Economic inclusion and economic well-being, which are related by definition, report a large correlation estimate. Similarly, households that engage more in civic/cultural activities tend to participate more in political activities. Albeit smaller in comparison, other estimates are also considerably large, manifesting high relevance of the multidimensional model.

Second, as presented in Table 4 , some poverty dimensions confer large effects on other dimensions, signifying their influential roles in determining the latter. Since the effect of one dimension on another can adopt direct and indirect paths, the testing of effects hypothesis should heed total effects. The total standardized effects reported in Table 4 take into account the direct and indirect effects, representing the total change in one poverty dimension score due to a unit change in another dimension score.9' The capability dimension appears to affect all other dimensions, whereas none affects it. Although capability is relatively highly correlated

Table 3. Correlation among poverty estimates produced by the model $(n=610)$

\begin{tabular}{lccccccc}
\hline & $\begin{array}{c}\text { Subjective } \\
\text { Economic } \\
\text { Well-being }\end{array}$ & $\begin{array}{c}\text { Objective } \\
\text { Economic } \\
\text { Well-being }\end{array}$ & $\begin{array}{c}\text { Economic } \\
\text { Well-being }\end{array}$ & Capability & $\begin{array}{c}\text { Economic } \\
\text { Inclusion }\end{array}$ & $\begin{array}{c}\text { Political } \\
\text { Inclusion }\end{array}$ & $\begin{array}{c}\text { Civic/ } \\
\text { Cultural } \\
\text { Inclusion }\end{array}$ \\
\hline $\begin{array}{c}\text { Subjective } \\
\text { Economic } \\
\text { Well-being }\end{array}$ & 1 & & & & & & \\
$\begin{array}{c}\text { Objective } \\
\text { Economic } \\
\text { Well-being }\end{array}$ & 0.534 & 1 & & & & & \\
$\begin{array}{c}\text { Economic } \\
\text { Well-being }\end{array}$ & 0.822 & 0.65 & 1 & & & \\
$\begin{array}{c}\text { Capability } \\
\text { Economic } \\
\text { Inclusion }\end{array}$ & 0.786 & 0.677 & 0.535 & 0.824 & 0.862 & 1 & \\
$\begin{array}{c}\text { Political } \\
\text { Inclusion }\end{array}$ & 0.412 & 0.325 & 0.501 & 0.479 & 0.503 & 1 & \\
$\begin{array}{c}\text { Civic/Cultural } \\
\text { Inclusion }\end{array}$ & 0.514 & 0.406 & 0.625 & 0.598 & 0.515 & 0.802 \\
\hline
\end{tabular}




\section{U. Wagle}

Table 4. Total standardized effects of each latent concept on others

\begin{tabular}{|c|c|c|c|c|c|c|c|}
\hline Dimensions & $\begin{array}{l}\text { Subjective } \\
\text { Economic } \\
\text { Well-being }\end{array}$ & $\begin{array}{l}\text { Objective } \\
\text { Economic } \\
\text { Well-being }\end{array}$ & $\begin{array}{l}\text { Economic } \\
\text { Wellbeing }\end{array}$ & Capability & $\begin{array}{l}\text { Economic } \\
\text { Inclusion }\end{array}$ & $\begin{array}{l}\text { Political } \\
\text { Inclusion }\end{array}$ & $\begin{array}{l}\text { Civic/ Cultural } \\
\text { Inclusion }\end{array}$ \\
\hline $\begin{array}{l}\text { Subjective } \\
\text { Economic } \\
\text { Well-being }\end{array}$ & 1 & 0 & 0.822 & 0 & 0 & 0.412 & 0.514 \\
\hline $\begin{array}{l}\text { Objective } \\
\text { Economic } \\
\text { Well-being }\end{array}$ & 0 & 1 & 0.65 & 0 & 0 & 0.326 & 0.406 \\
\hline $\begin{array}{l}\text { Economic } \\
\text { Well-being }\end{array}$ & 0 & 0 & 1 & 0 & 0 & 0.501 & 0.625 \\
\hline Capability & 0 & 0 & 0.956 & 1 & 0.862 & 0.479 & 0.598 \\
\hline $\begin{array}{l}\text { Economic } \\
\text { Inclusion }\end{array}$ & 0 & 0 & 0 & 0 & 1 & 0 & 0 \\
\hline $\begin{array}{l}\text { Political } \\
\text { Inclusion }\end{array}$ & 0 & 0 & 0 & 0 & 0 & 1 & 0 \\
\hline $\begin{array}{l}\text { Civic/cultural } \\
\text { Inclusion }\end{array}$ & 0 & 0 & 0 & 0 & 0 & 0.802 & 1 \\
\hline
\end{tabular}

Note: The table is presented as an inverse of the $\mathbf{B}$ matrix.

with every other dimension, this unidirectional effect highlights the role of capability in driving all other poverty dimensions. Consistent with the human capital and capability poverty arguments (Becker, 1964; Lucas, 1988; Sen, 1992), the total standardized effect of capability on economic well-being and economic inclusion is almost one, indicating that one standard deviation change in the former will lead to almost one standard deviation change each in the latter. One of the most telling stories this model suggests is that education, which is at the core of all indicators of capability, is also at the epicenter of being able to meaningfully participate in the labor market and the larger economy, and deriving adequate income and consumption to escape poverty.

Overshadowed by these large effects are the relatively smaller effects of capability on political inclusion and civic/cultural inclusion. Again most crucial is the contribution that education makes to a household's participation in political as well as civic/cultural activities. While the finding regarding the primacy of education is self-explanatory, the level of education appears to have been determined independently of any other poverty dimension, thus evoking further clarifications. Command over resources and political or civic/cultural ties, for example, do not ensure higher levels of educational attainment. Partly, this is a precursor for the role of demographic factors in determining one's capability necessitating more complex models (Wagle, 2004b).

Economic well-being is another dimension that substantially affects political and civic/cultural inclusion, reaffirming the thesis that one needs a good command over resources to be able to meaningfully participate in political and social activities, which especially in contexts like this provide a license to hold political power and social recognition. No doubt, the 
unidirectional effect of economic well-being on political and civic/cultural inclusion and the complete absence of effects between economic inclusion and political and civic/cultural inclusion do not lend enough support for the argument that one needs political and social ties to secure a job or to engage in other economically lucrative activities (Opel, 2000; Grootaert, 2002). But some reverse causation might be at work, signifying that the command over resources is a prerequisite with its dominant roles in determining one's participation in politics and civil society.

Table 4 also records a relatively large effect of civic/cultural inclusion on political inclusion. The finding that those participating more in civic, cultural, and associational activities also tend to participate more intensely in political activities, including partisan activities, political contacts, and policy discussions, is consistent with suggestions elsewhere (Almond and Verva, 1963; Krishna, 2002; Putnam, 1993, 2000; Wagle, 2004c). Those who stay tuned in their communities also tend to be conscious of political issues surrounding them, thus encouraging their fuller participation. But the model does not detect any reverse causation that political inclusion might have on civic/cultural inclusion, perhaps indicating a contrast between the relatively nascent political culture and the rich social and civic culture this society is historically accustomed to, even after the restoration of multiparty democracy in 1990 .

\section{Poverty measurement}

The use of a comprehensive operational definition suggests that identifying poverty status would involve looking at one's scores on all poverty dimensions. The summary statistics provided in Table 5 indicate that whereas all scores are centered on zero, signifying their normalized characteristics, their distributions are different. Large distributions suggest that household statuses on a particular poverty dimension are highly unequal whereas smaller ones indicate less inequality. Particularly noticeable is the distribution of capability dimension scores, which are highly concentrated, indicating their smaller variance, compared with the relatively large variance of the economic inclusion scores.

While researchers use absolute, relative, or subjective approaches to establish poverty standards, the absolute approach dominates the entire field of poverty research (Citro and Michael, 1995; Haveman, 1987; Wagle, forthcoming). Although the absolute approach is used to identify income

Table 5. Summary statistics of poverty dimensions $(n=608)$

\begin{tabular}{lcccc}
\hline Dimension & Mean & Standard Deviation & Minimum & Maximum \\
\hline Economic Well-being & -0.007 & 0.617 & -1.939 & 1.705 \\
Capability & -0.002 & 0.163 & -0.538 & 0.410 \\
Economic Inclusion & -0.010 & 0.589 & -2.291 & 1.267 \\
Political Inclusion & 0.006 & 0.453 & -1.148 & 1.330 \\
Civic/Cultural Inclusion & 0.004 & 0.762 & -2.071 & 2.495 \\
\hline
\end{tabular}


or consumption poverty standards, this paper stems from the argument that the same can be applied to identify capability or social inclusion poverty standards (Wagle, 2002). ${ }^{10}$ In an attempt to identify alternative ways to use the produced scores, I use some existing poverty estimates in Kathmandu. Without further ado, I apply $30 \%$ and $40 \%$ poverty estimates provided by other studies using income and consumption standards. ${ }^{11}$

Different ways exist to aggregate poverty dimension scores, however. First, poverty status can be ascertained, based on each of the poverty dimensions separately, with the results aggregated using some highly plausible assumptions. While differential weights could be used, this alternative would be primarily unweighted since poverty status is identified separately on each of the poverty dimensions. Second, the absolute scores can be aggregated to derive one single set of overall poverty scores, assuming equal or differential weights. This set of final poverty scores could be used for absolute or relative purposes, with the former requiring some pre-established criteria to define what value is associated with particular poverty status, ${ }^{12}$ and the latter (used here) invoking derivation of more simple, relative thresholds. Although other alternatives also exist, ${ }^{13}$ I focus on these two.

Under the first alternative, the poverty status of households is identified for each of the five poverty dimensions, using 30\% and $40 \%$ poverty estimates. Because social inclusion is the aggregate of economic, political, and civic/cultural inclusion dimensions, the social inclusion poverty status of households is identified by applying an arbitrary but realistic assumption that poor households would manifest poverty on at least two of the three social inclusion dimensions. The three poverty dimensions that I refer to, hereinafter, would thus indicate economic wellbeing, capability, and social inclusion dimensions. Given the poor or nonpoor status of households, further aggregation would detail the intensity of poverty experienced by households. In effect, households experiencing poverty on all three dimensions are considered 'abject poor' as they are deeply entrenched in poverty, with minimal likelihood of escape. ${ }^{14}$ Households experiencing poverty on two dimensions are considered 'very poor,' as they are at risk of being the abject poor but are slightly better positioned. All other households that are poor on only one of the three dimensions are considered 'poor,' which are relatively better off with much higher chance of escaping poverty.

Table 6 indicates that the application of this comprehensive definition along with $30 \%$ and $40 \%$ poverty estimates would categorize close to $40 \%$ and $50 \%$ of the households as the poor in general. About $10 \%$ of the households would fall into the categories of poor and very poor each, whereas close to $20 \%$ and $30 \%$ would fall in the category of abject poor. The difference between using $30 \%$ and $40 \%$ estimates would be chiefly on having the size of the abject poor 10 percentage points apart, with the proportion of the very poor and poor remaining unchanged. Similarly, Table 6 suggests that the economic well-being and capability poor tend to 
Table 6 . Household poverty status suggested by unweighted scores

\begin{tabular}{|c|c|c|c|c|c|c|c|c|c|c|c|}
\hline \multicolumn{2}{|c|}{ Dimension/ Poverty Status } & \multicolumn{5}{|c|}{ Status Using $30 \%$ Poverty Rate } & \multicolumn{5}{|c|}{ Status Using $40 \%$ Poverty Rate } \\
\hline & & \multirow{2}{*}{$\begin{array}{c}\text { Non-poor } \\
60.9\end{array}$} & \multirow{2}{*}{$\begin{array}{c}\text { Poor } \\
8.9\end{array}$} & \multirow{2}{*}{$\begin{array}{r}\text { Very } \\
\text { Poor }\end{array}$} & \multirow{2}{*}{$\begin{array}{c}\begin{array}{c}\text { Abject } \\
\text { Poor }\end{array} \\
19.9\end{array}$} & Total & Non-poor & Poor & \multirow{2}{*}{$\begin{array}{c}\begin{array}{c}\text { Very } \\
\text { Poor }\end{array} \\
9.7\end{array}$} & $\begin{array}{c}\text { Abject } \\
\text { Poor }\end{array}$ & Total \\
\hline Total & & & & & & 100.0 & 49.8 & 10.7 & & 29.8 & 100.0 \\
\hline \multirow{2}{*}{ Economic Well-being } & Non-poor & 60.9 & 8.6 & 0.7 & 0 & 70.1 & 49.8 & 9.4 & 0.7 & 0 & 59.9 \\
\hline & Poor & 0 & 0.3 & 9.7 & 19.9 & 29.9 & 0 & 1.3 & 9.0 & 29.8 & 40.1 \\
\hline \multirow[t]{2}{*}{ Capability } & Non-poor & 60.9 & 8.1 & 1.2 & 0 & 70.1 & 49.8 & 9.4 & 0.7 & 0 & 59.9 \\
\hline & Poor & 0 & 0.8 & 9.2 & 19.9 & 29.9 & 0 & 1.3 & 9.0 & 29.8 & 40.1 \\
\hline \multirow[t]{2}{*}{ Social Inclusion } & Non-poor & 60.9 & 1.2 & 8.6 & 0 & 70.6 & 49.8 & 2.6 & 8.4 & 0 & 60.9 \\
\hline & Poor & 0 & 7.7 & 1.8 & 19.9 & 29.4 & 0 & 8.1 & 1.3 & 29.8 & 39.1 \\
\hline \multicolumn{12}{|c|}{$\begin{array}{l}\text { Notes: } \\
\text { 1) All values are as a percentage of the total households }(\mathrm{N}=608) \\
\text { 2) Poverty categorization is as follows: non-poor }=\text { not poor on all dimensions; poor=poor on at least one dimension; } \\
\text { very poor = poor on any two dimensions; abject poor }=\text { poor on all three dimensions } \\
\text { 3) The values are non-cumulative indicating, for example, that the abject poor are not included in the very poor, who are not included in the poor }\end{array}$} \\
\hline
\end{tabular}




\section{U. Wagle}

be more similar whereas the social inclusion poor tend to be somewhat different, as a considerable percentage of the non-poor on social inclusion dimension have also fallen into poor and very poor categories of the overall poverty dimension.

Table 7 presents poverty measurement outcomes following the second alternative using weighted scores. With the motivation of analyzing sensitivity with respect to outcomes, I apply various weighting schemes, all using the $40 \%$ poverty estimate. ${ }^{15}$ The process involved combining the economic, political, and civic/cultural inclusion dimension scores into one set of social inclusion scores and then applying different weighting schemes to aggregate the scores into the final set of overall poverty scores. Largely consistent with the outcomes presented in Table 6 using the 30\% estimate, poverty rates of $10 \%, 10 \%$, and $20 \%$ were used to categorize the poor, very poor, and abject poor.

The resulting, highly symmetric poverty categorization outcomes indicate that the outcomes are most conforming between using $75 \%$ weights on the capability and economic well-being dimensions. Using equal weight does not appear to provide much different poverty categorization outcomes either. Assigning the highest weight to the social inclusion dimension, however, provides highly contrasting poverty measurement outcomes. Whereas $60 \%$ of the households were non-poor in each individual scenario, only $36 \%, 31 \%$, and $32 \%$ of the households would be consistently categorized as non-poor, as suggested by the use of high weight on social inclusion dimension, and the use of equal weight and high weights on capability and economic well-being dimensions.

\section{Discussions and conclusion}

Estimation of the multidimensional model of poverty suggests several important findings. The finding that select indicators are appropriate to measure poverty dimensions insinuates that policy-makers refocus on each of the thematic policy areas differently. First, although consumption itself and subjective views on the adequacy of income are important, one can easily deduce from the leading role of income in this highly urbanized setting that the major policy concern to improve economic well-being should be on increasing household income. Paid employment being the major source of income in Kathmandu, especially for the economically less well-off households, ${ }^{16}$ the highly inadequate wages these households receive require serious attention. ${ }^{17}$ Second, consistent with the realization by the World Bank (2003b), the UNDP (2002), and others, providing educational opportunities especially for women and providing health care facilities appear to be more fundamental at enhancing capability. The role of education, however, can be the most central of all in a society in which a lack of education is clearly linked to one's inability to maintain good health together with practices that undermine the economic and other potentials of daughters. 
Table 7. Household poverty status suggested by weighted scores (using $40 \%$ poverty rate)

\begin{tabular}{|c|c|c|c|c|c|c|c|c|c|c|c|c|c|c|}
\hline \multirow[t]{2}{*}{ Weight/Poverty Status } & & \multirow[t]{2}{*}{ Total } & \multicolumn{4}{|c|}{ Equal Weight } & \multicolumn{4}{|c|}{ Economic Well-being $75 \%$} & \multicolumn{4}{|c|}{ Capability $75 \%$} \\
\hline & & & Non-poor & Poor & $\begin{array}{l}\text { Very } \\
\text { Poor }\end{array}$ & $\begin{array}{l}\text { Abject } \\
\text { Poor }\end{array}$ & Non-poor & Poor & $\begin{array}{l}\text { Very } \\
\text { Poor }\end{array}$ & $\begin{array}{l}\text { Abject } \\
\text { Poor }\end{array}$ & Non-poor & Poor & $\begin{array}{l}\text { Very } \\
\text { Poor }\end{array}$ & $\begin{array}{c}\text { Abject } \\
\text { Poor }\end{array}$ \\
\hline \multirow{5}{*}{$\begin{array}{l}\text { Total } \\
\text { Economic Well-being } 75 \%\end{array}$} & & 100.0 & 60.0 & 9.9 & 10.0 & 20.1 & 60.0 & 9.9 & 10.0 & 20.1 & 59.9 & 10.0 & 10.0 & 20.1 \\
\hline & Non-poor & 60.0 & 54.9 & 3.6 & 1.3 & 0.2 & & & & & & & & \\
\hline & Poor & 9.9 & 4.3 & 3.1 & 1.6 & 0.8 & & & & & & & & \\
\hline & Very Poor & 10.0 & 0.8 & 2.8 & 4.1 & 2.3 & & & & & & & & \\
\hline & Abject Poor & 20.1 & 0 & 0.3 & 3.0 & 16.8 & & & & & & & & \\
\hline \multirow[t]{4}{*}{ Capability $75 \%$} & Non-poor & 59.9 & 55.6 & 3.3 & 0.8 & 0.2 & 57.9 & 2.0 & 0 & 0 & & & & \\
\hline & Poor & 10.0 & 3.9 & 3.5 & 2.1 & 0.5 & 2.1 & 7.1 & 0.82 & 0 & & & & \\
\hline & Very Poor & 10.0 & 0.5 & 2.8 & 4.6 & 2.1 & 0 & 0.8 & 8.4 & 0.8 & & & & \\
\hline & Abject Poor & 20.1 & 0 & 0.3 & 2.5 & 17.3 & 0 & 0 & 0.8 & 19.2 & & & & \\
\hline \multirow[t]{4}{*}{ Social Inclusion $75 \%$} & Non-poor & 59.9 & 36.3 & 5.4 & 6.3 & 11.8 & 31.4 & 6.9 & 6.4 & 15.1 & 32.1 & 6.6 & 6.6 & 14.6 \\
\hline & Poor & 10.2 & 6.4 & 1.2 & 1.0 & 1.6 & 6.6 & 1.0 & 1.2 & 1.5 & 6.7 & 0.8 & 1.0 & 1.6 \\
\hline & Very Poor & 10.0 & 7.2 & 0.7 & 0.8 & 1.3 & 7.9 & 0.5 & 0.7 & 1.0 & 7.4 & 1.0 & 0.7 & 1.0 \\
\hline & Abject Poor & 19.9 & 10.0 & 2.6 & 2.0 & 5.3 & 14.1 & 1.5 & 1.8 & 2.5 & 13.7 & 1.6 & 1.8 & 2.8 \\
\hline \multicolumn{15}{|c|}{$\begin{array}{l}\text { Notes: } \\
\text { 1) All values are as a percentage of the total households }(\mathrm{N}=608) \\
\text { 2) A weight of } 75 \% \text { for one dimension implies that the remaining two dimensions are weighted at } 12.5 \% \text { each } \\
\text { 3) The assumed poverty rate: non-poor }=\text { top } 60 \% \text {; poor }=\text { next } 10 \% \text {; very poor }=\text { next } 10 \% \text {; abject poor }=\text { bottom } 20 \% \\
\text { 4) The values are non-cumulative indicating, for example, that the abject poor are not included in the very poor, who are not included in the poor }\end{array}$} \\
\hline
\end{tabular}


Third, promoting inclusion of households in the labor market and other economic activities invokes policies focusing on preparing skilled manpower, creating employment opportunities, and providing access to institutional finances. In a society where there are stark social and economic discrepancies between skilled and unskilled jobs, and where new entrepreneurs lack the needed financial support, appropriate policy initiatives can make a difference. Fourth, although electoral and other forms of political participation in Nepal dramatically increased in the early 1990s, thanks to the restoration of multiparty democracy that energized people to participate, it effectively waned away by the end of the 1990s (Wagle, 2004c).$^{18}$ In Nepal, with a nascent political culture and a long history of authoritarian regime, policies targeted at strengthening political inclusion should focus on measures to increase electoral participation, raise citizen awareness of the political process and policy issues, and facilitate communication between voters and political leaders. Moreover, although Kathmandu has a rich heritage of holding civic and cultural activities, its increasingly urban setting with a large migrant population poses a serious challenge for policy-makers seeking to promote inclusion of isolated groups and communities. Findings suggest that expanding the civil society sector with increased citizen participation in both registered and unregistered organizations or groups and with increased emphasis on self-help activities can be the focus of policies aimed at promoting civic/ cultural inclusion.

Next, the model conspicuously supported the multidimensionality hypothesis, suggesting that the theoretically supported dimensions of poverty are in fact all related, with the ability to reveal more realistically the overall poverty status of households. Economic well-being, the focus of most contemporary analyses, constitutes only one of several dimensions of poverty, and, albeit important, does not provide a realistic picture. Furthermore, income and consumption that are at the core of avoiding hunger, malnutrition, and deprivation do not necessarily predict the outcomes in terms of the overall living conditions and state of human wellbeing. This analysis strongly supports that economic well-being helps transform capability into other activities indicative of living conditions, including political and civic/cultural inclusion. What is more fundamental from the social policy perspective is the capability that overwhelmingly contributes to acquiring economic well-being, obviously because education can be a prerequisite to having adequate income or consumption. More educated or more informed people, for example, are less likely to be poor not only because they are better prepared for employment, but also because they make more informed decisions in acquiring or managing resources as well as making other life decisions. Consistent with the capability arguments (Sen, 1992, 1999; UNDP, 2000a,b; Sparkes and Glennerster, 2002; World Bank, 2003b; Wagle, 2004b), the overall capability of a household is a strong predictor of all other dimensions of poverty. 
The model further insinuates that economic and political inclusions are result dimensions, and do not affect other dimensions. Contrary to what one would normally expect, participation in the labor market, access to financial resources such as bank credit, and involvement in different economic activities do not predict one's real gain from the economy, whether it is in the form of capability or economic well-being. The same holds true for political participation. While political participation or being included in political circles and networks is thought to be important, especially in economies where the public sector predominates and the share of the private sector is minimal, the overall capability, command over resources, and the level of integration in the community and larger civil society collectively determine a household's extent of political inclusion. Political participation necessitates rational actions regarding what is beneficial and what is not, which can be costly in today's modern world. Lacking knowledge about public affairs in a particular locality or nation, households may not know the process and the outcomes of political participation. This may be more the case in a society in which politics is a game largely dominated by those in power, with very little competition from outsiders (Bista, 1991). It is a form of exclusion in which a small minority with information and power can manipulate the vulnerable majority, effectively denying them the basic rights including rights to govern themselves. Although integration in the civil society and culture has a generally positive impact on poverty status of households, this analysis does not detect its direct role in improving the economic wellbeing conditions, as is sometimes argued (Grootaert, 2002).

Since this model predicts household scores on all five dimensions, it provides more comprehensive information that is useful to predict the overall poverty status of households. Undoubtedly, those at the bottom end of the distribution of different poverty dimension scores will be the poorest of the poor. But who can be categorized as poor and who as nonpoor is a political issue, since generally the government policy may effectively reduce or increase the proportion of population living in poverty. Although the scores presented capture the absolute status of households on each of the poverty dimensions, their highly objective nature makes their absolute use more complicated, thus invoking the necessity to focus on their relative use instead. Concluding that a household is situated at the top, middle, or bottom levels of the distribution, for example, conveys a more specific message than simply providing -0.023 or 0.23 as an absolute dimension score. This comparative perspective, if appropriately used, can be valuable to ascertain whether a household is poor or not, provided that there is a common understanding on the specific poverty threshold. Income or consumption poverty thresholds convey simple and easily understandable connotations due to their monetary measurement (Citro and Michael, 1995; Wagle, 2002, forthcoming). What fails to be recognized, however, is the arbitrary and political nature of these poverty standards. The widely 
used international poverty standard with a threshold of one-dollar-a-day income, for example, makes an implicit assumption for a 'wise' use of income - otherwise its appeals would fail. Similarly, the consumption poverty standards, set at certain calories of food that assume a proper combination of different nutritional ingredients, can easily be contested or violated. Often, policy-makers weigh in the consequences of having a higher or a lower threshold of poverty, using sensitivity analyses, so that establishing appropriate and politically amenable poverty standards counts as common policy framework, such as health care, education, and crime fighting.

Until some widely agreed-upon estimate of poverty, or a criterion to demarcate the poor from the rest, is identified on each of the poverty dimensions, analysts can draw from poverty estimates provided by others. The use of $30 \%$ and $40 \%$ poverty estimates in Kathmandu was an example of this. The finding based on these estimates that $20 \%$ and $30 \%$ would be the poorest of the poor is very useful, especially from a policy standpoint, since the identification of the abject poor would help policy-makers to better target welfare or other development aid. Identification of the very poor households making up almost $10 \%$ in both cases is another valuable policy contribution, suggesting that this group should be the next priority of the government. Irrespective of the poverty estimates used, the usefulness of the multidimensional approach lies in its ability to provide information on the relative poverty status of households in which those at the bottom are the poorest, needing the most extensive array of public and policy resources. This is more the case in societies like Nepal, and more specifically Kathmandu, where the government faces the recurrent challenge to better allocate extremely scarce resources.

Assigning appropriate weight is important because using weighted scores yields considerably different measurement outcomes, especially when the social inclusion dimension was weighted the highest. Weighting social inclusion more heavily resulted in outcomes that were highly unpredictable, compared with using economic well-being and capability dimension scores. Not every dimension is equally important. How much weight each deserves depends on the particular society under consideration. More urbanized and/or monetized societies, for example, would put more weight on economic well-being, which would be different from more communitarian - perhaps including rural - societies that may put more weight on social solidarity and cohesiveness. This makes a strong case that assigning proper weight to each of the poverty dimensions is immensely crucial to realistically identifying the poverty status of households. While this might serve as another policy arena letting governments politicize the issue of poverty measurement, social preferences indicating the value of each poverty dimension should be an integral part of poverty analysis, since which weighting scheme is more appropriate largely depends on the particular value system that a society upholds. Thus, future 
research should focus on identifying a weighting scheme that is consistent with the value system in a given society and culture. Social science research can offer much on this by applying survey methodologies that attempt to elicit people's true preferences.

Another issue for future research relates to the indicators of poverty dimensions. Data on more exhaustive list of indicators should be collected and processed to develop more robust models. Also needed are large and preferably cross-national studies to derive findings that may be generalized for a wider application of this multidimensional approach.

\section{Notes}

1 Attempts to incorporate multiple dimensions of poverty have historically been inspired by Adelman and Morris's $(1967,1973)$ work that sought to quantify the extent of economic development using a number of indicators and to identify social, cultural, political, and other policy variables that influence it. Their focus, however, was on macro indicators that helped to identify the state of economic development in a number of developing countries.

2 A recent national living standard survey, for example, concludes that the incidence of poverty in the country has declined from $42 \%$ in 1996 to $30 \%$ in 2002 (Kathmandu Post, 2004a). While the poverty standard estimated at consumption of 2124 food calories per day has remained unchanged, the revised poverty estimate has been reported citing an overwhelming increase in foreign remittance (Kathmandu Post, $2004 \mathrm{~b})$. The question is whether this increase in income automatically enables people to secure the established consumption standards.

3 Out of these households, however, only 610 had complete data, thus making an effective sample size of 610 .

4 While there are five dimensions of poverty represented by the $\eta$ values, the actual operationalization used here includes two other latent concepts, including objective and subjective economic well-being, which together form the economic well-being dimension. Accommodating these changes, the model embodies seven $\eta$ values, suggesting that the first part of the model includes seven equations. In this case, there will be seven elements of the $\boldsymbol{\eta}$ vector throughout. This can be easily verified in the final model presented in Figure 1 later.

5 This final model is identified using the $t$ - and two-step rules (Bollen, 1989). While I could manually establish identification using these rules, the use of standard software automatically does so in an attempt to estimate structural equation modeling models and reports any identification problem. The MPlus software used here indicated that the final version of the model was in fact identified.

6 The addition of two latent concepts forming the economic well-being dimension adds an additional layer to the model, thus increasing the number of parameters to be estimated and contributing to its complexity.

7 The exploratory factor analysis helps identify principal components based on their factor loadings on the hypothesized latent factor. This is an additional tool applied herein to test whether the appropriateness of the indicators suggested by the literature really holds with a single factor analysis model estimated for each dimension.

8 Albeit seemingly arbitrary, these four occupational categories have much in common with regard to their economic incentives and social recognition. Households with householders in these occupations tend to make substantially lower incomes - on average NRS32 000 annual per capita compared with NRS57000 for all other households. While armed forces and especially labor occupations have much lower payoffs - on average associated households having annual per-capita income of 


\section{U. Wagle}

NRS28000 and NRS14000 respectively - households associated with all four occupations included in this combined category had annual per-capita income of less than NRS50000. These occupations also indicate low-prestige jobs in this urban center, where, unlike in much of the country, people are engaged in a wide variety of occupations. Conversely, the executive and professional occupation, another category included in the analysis, carries considerably higher prestige and higher economic payoff - on average the associated households have an annual per-capita income of NRS60000 compared with NRS50000 for all other households.

9 More formally, it is the change in $\eta_{i}$ associated with a unit shock to $\eta_{j}$, which can be computed using $[\mathbf{I}-\mathbf{B}]^{-1}$ where $\mathbf{I}$ is the identity matrix and $\mathbf{B}$ is the matrix of coefficients loading on $\eta_{1}, \eta_{2}, \eta_{3}, \eta_{4}$, and $\eta_{5}$. This expression derives directly from $\boldsymbol{\eta}=\mathbf{B} \boldsymbol{\eta}+\varsigma$.

10 Assumed for illustrative purposes, this is not to imply that the inequality of capability and social inclusion will be identical to that of economic well-being. Societies may be more or less economically, capabilistically, or social inclusively equal compared with poverty dimensions other than the one under consideration. Again, this begs a difficult question of how to define poverty using each of the dimensions, which, albeit partly indicated by the distribution of dimension scores, is linked with the absolute versus relative concepts of poverty.

11 The national poverty rate suggested by the Central Bureau of Statistics (1997) using the consumption-income poverty standard was slightly over $40 \%$ in 1996 , the revised estimate for which was 30\% in 2003 (Kathmandu Post, 2004a). While other studies (Wagle, forthcoming) have suggested different estimates using income, consumption, and relative poverty standards, using $30 \%$ and $40 \%$ estimates provide two reasonable alternatives for Kathmandu, given its relatively high poverty rates on economic wellbeing as well as other dimensions.

12 This alternative would necessitate extensive work to ascertain the contribution of each of the poverty dimensions, and therefore their indicators to categorize one as poor or non-poor. It would also involve tremendous value judgments to decide how particular values for particular indicators could be compensatory for others, leaving the likelihood of the household of being poor unchanged.

13 One alternative, for example, is to use scores on all five dimensions to ascertain separate poverty status of households with some more elaborate assumptions. Another would be using mean or median scores to identify household poverty status on each of the dimensions.

14 This might be closer to the concept of chronic poverty defined as being consistently poor for more than five years, which is in vogue among some poverty researchers (Hulme et al., 2001; Hulme and Shepherd, 2003; Metha and Shah, 2003). Although the focus of these researchers is basically on the time dimension, the concept of abject poverty goes beyond - incorporating its multiple dimensions.

15 This is shown for illustrative purposes only. The same can be computed using the $30 \%$ poverty estimate.

16 The survey data show, for example, that $82 \%$ of the income for households with $50 \%$ of the median income, in which at least one member is employed in unregistered businesses, derives from wages. This is substantially higher compared with $51 \%$ of the income for households with income above $50 \%$ of the median and $34 \%$ for all households.

17 The prevailing minimum wage for unskilled workers was NRS1450 (or US\$20) per month, which was far below the international poverty line. Even this minimum wage is not strictly adhered to in the unorganized, informal sector in which people from these low-income households are engaged.

18 There are widely held arguments that this political apathy has resulted from large inefficiencies of the democratically elected governments to meet the mass expectation for long-awaited social and economic reform in the country (Hachhethu, 2004; PfaffCzarnecka, 2004; Wagle, 2005). 


\section{References}

Adelman, I. and Morris, C.T. (1967) Society, Politics, and Economic Development, Johns Hopkins University Press, Baltimore, MD.

Adelman, I. and Morris, C.T. (1973) Economic Growth and Social Equity in Developing Countries, Stanford University Press, Standford.

Almond, G. and Verba, S. (1963) The Civic Culture, The Princeton University Press, Princeton, NJ.

Amis, P. and Rakodi, C. (1994) 'Urban poverty: issues for research and policy', Journal of International Development, 6(5), pp. 267-634.

Atkinson, A.B. (1998) 'Social exclusion, poverty and unemployment', in A. Atkinson and J. Hills (Eds), Exclusion, Employment and Opportunity, CASE/London School of Economics, London.

Baker, R., Panter-Brick, C. and Todd, A. (1997) 'Homeless street boys in Nepal: their demography and lifestyle', Journal of Comparative Family Studies, 28(1), pp. 128-146.

Beall, J. (1997) 'Assessing and responding to urban poverty', IDS Bulletin, 28(2), pp. 59-67.

Becker, G.S. (1964) Theoretical and Empirical Analysis with Reference to Education, National Bureau of Economic Research, New York.

Bista, D.B. (1991) Fatalism and Development: Nepal's Struggle for Modernization, Orient Longman, Calcutta.

Bollen, K.A. (1989) Structural Equations with Latent Variables, John Wiley \& Sons, New York.

Burchardt, T., Le Grand, J. and Piachaud, D. (2002) 'Degrees of exclusion: developing a dynamic, multidimensional measure', in T. Burchardt, J. Le Grand and D. Piachaud (Eds), Understanding Social Exclusion, Oxford University Press, London.

Cannan, C. (1997) 'The struggle against social exclusion: urban social development in France', IDS Bulletin, 28(2), pp. 77-85.

Castel, R. (2000) 'The roads to disaffiliation: insecure work and vulnerable relationships', International Journal of Urban and Regional Research, 24(3), pp. 519-535.

Central Bureau of Statistics (1997) Nepal Living Standard Survey Report 1996 - Main Findings, volume 1, CBS, Kathmandu.

Central Bureau of Statistics (2002) Population of Nepal: Population Census 2001 Selected Tables (Central Development Region), CBS, Kathmandu.

Chatterjee, P. (1999) 'Shadow lives: urban India's informal economy', Habitat Debate, 5(4), pp. 4-6.

Checchi, D. and Lucifora, C. (2000) 'Education, mobility, and poverty - an Italian perspective: introduction', International Journal of Manpower, 21(3/4), pp. 155-159.

Citro, C.F. and Michael, R.T. (1995) Measuring Poverty: A New Approach, National Academy Press, Washington, DC.

de Haan, A. and Maxwell, S. (1998) 'Poverty and social exclusion in north and south', IDS Bulletin, 29(1), pp. 10-19.

Dewlide, C. (2004) 'The multidimensional measurement of poverty in Belgium and Britain: a categorical approach', Social Indicators Research, 68(3), pp. 1-39.

de Wit, J.W. (1996) Poverty, Policy, and Politics in Madras Slums: Dynamics of Survival, Gender, and Leadership, Sage Publications, Thousand Oaks, CA.

European Foundation (1995) Public Welfare Services and Social Exclusion: The Development of Consumer Oriented Initiatives in the European Union, The European Foundation for the Living and Working Conditions, Dublin.

Evans, M. (1998) 'Behind the rhetoric: the institutional basis of social exclusion and poverty', IDS Bulletin, 29(1), pp. 42-49.

Figueroa, A., Altamirano, T. and Sulmont, D. (1996) 'Social exclusion and inequality in Peru', Research Series 104, International Institute for Labour Studies, Geneva.

Garson, D. (2003) 'Structural equation modeling', mimeo, North Carolina State University.

Gore, C. and Figueiredo, J.B. (Eds) (1997) 'Social exclusion and anti-poverty policy: debate', Research Paper 110, International Institute for Labour Studies, Geneva. 


\section{U. Wagle}

Gore, C., Figueiredo, J.B. and Rodgers, G. (1995) 'Introduction: markets, citizenship and social exclusion', in G. Rodgers, C. Gore and J.B. Figueiredo (Eds), Social Exclusion: Rhetoric, Reality, Responses, International Institute for Labour Studies, Geneva.

Grootaert, C. (2002) 'Quantitative analysis of social capital data', in C. Grootaert and T. van Bastelaer (Eds.), Understanding and Measuring Social Capital: A Multidisciplinary Tool for Practitioners, The World Bank, Washington, DC.

Gunatilleke, G. and Perera, M. (1994) 'Urban poverty in Sri Lanka: critical issues and policy measures', Asian Development Review, 12(1), pp. 153-203.

Hachhethu, K. (2004) 'The Nepali state and the Maoist insurgency, 1996-2001', in M. Hutt (Ed.), Himalayan People's War: Nepal's Maoist Rebellion, Indiana University Press, Bloomington.

Haveman, R.H. (1987) Poverty Policy and Poverty Research: The Great Society and Social Sciences, University of Wisconsin Press, Madison.

Hulme, D. and Shepherd, A. (2003) 'Conceptualizing chronic poverty', World Development, 31(3), pp. 403-423.

Hulme, D., Moore, K. and Shepherd, A. (2001) 'Chronic poverty: meanings and analytical frameworks', Working Paper 2, Chronic Poverty Research Centre, London.

International Institute of Labour Studies (1996) Social Exclusion and Anti-Poverty Strategies, IILS, Geneva.

International Labour Organization (1976) Meeting Basic Needs: Strategies for Eradicating Mass Poverty and Unemployment, ILO, Geneva.

Jordan, B. (1996) A Theory of Poverty and Social Exclusion, Polity Press, Cambridge.

Kathmandu Metropolitan City (2003) 'List of urban indicators for urban planning of KMC', mimeo, Katbmandu.

Kathmandu Post (2004a) 'Absolute poverty down to 30 percent' (news report), The Kathmandu Post, 10 November.

Kathmandu Post (2004b) 'Poverty confusion' (editorial), The Kathmandu Post, 16 November.

Khundker, N., Wahiddudin, M., Sen, B. and Ahmed, M.U. (1994) 'Urban poverty in Bangladesh: trends, determinants, and policy issues', Asian Development Review, 12(1), pp. 1-31.

Krishna, A. (2002) 'Enhancing political participation in democracies: what is the role of social capital?', Comparative Political Studies, 35(4), pp. 437-460.

Lucas, R.E. (1988) 'On the mechanisms of economic development', Journal of Monetary Economics, 22(1), pp. 3-42.

MacPherson, S. and Silburn, R. (1998) 'The meaning and measurement of poverty', in J. Dixon and D. Macarov (Eds), Poverty: A Persistent Global Reality, Routledge, New York.

Metha, A.K. and Shah, A. (2003) 'Chronic poverty in India: incidence, causes, and policies', World Development, 31(3), pp. 491-511.

Moser, C.O.N. (1998) 'The asset vulnerability framework: reassessing urban poverty reduction strategies', World Development, 26(1), pp. 1-19.

Muellbauer, J. (1987) 'Professor Sen on the standard of living', in G. Hawthorn (Ed.), The Standard of Living, The Tanner Lectures (Cambridge, 1985), Cambridge University Press, New York.

Muthen, L.K. and Muthen, B.O. (2001) MPlus User's Guide, 2nd edition, Muthen \& Muthen, Los Angeles.

National Planning Commission (1992) Poverty Alleviation and Human Development in Nepal, NPC, Kathmandu.

Opel, A.E. (2000) 'The social content of labor markets in Dhaka slums', International Journal of Development, 12(5), pp. 735-750.

Orshansky, M. (1965) 'Counting the poor: another look at the poverty profile', in L.A. Ferman, J.L. Kornbluh and A. Haber (Eds), Poverty in America: A Book of Readings, University of Michigan Press, Ann Harbor.

Oyen, E. (1995) 'The contradictory concepts of social exclusion and social inclusion', in C. Gore and J.B. Figueiredo (Eds), Social Exclusion and Antipoverty Policy: A Debate, Research Series 110, International Institute for Labour Studies, Geneva. 
Pfaff-Czarnecka, J. (2004) 'High expectations, deep disappointment: politics, state and society in Nepal after 1990', in M. Hutt (Ed.), Himalayan People's War: Nepal's Maoist Rebellion, Indiana University Press, Bloomington.

Pradhan, M. and Ravallion, M. (2000) 'Measuring poverty using qualitative perceptions of consumption adequacy', Review of Economics and Statistics, 82(3), pp. 462-471.

Putnam, R. (1993) Making Democracy Work: Civic Traditions in Modern Italy, Princeton University Press, Princeton, NJ.

Putnam, R. (2000) Bowling Alone, Simon \& Schuster, New York.

Ravallion, M. (1996) 'Issues in measuring and modeling poverty', Economic Journal, 106(September), pp. 1328-1343.

Rowntree, S. (1901) Poverty: A Study of Town Life, Macmillan, London.

Ruel, M.T., Haddad, L. and Garrett, J.L. (1999) 'Some urban facts of life: implications for research and policy', World Development, 27(11), pp. 1917-1938.

Satterthwaite, D. (1995) 'The underestimation of urban poverty and of its health consequences', Third World Planning Review, 17(4), pp. iii-xii.

Sen, A.K. (1987) 'The standard of living: lecture II, lives and capabilities', in G. Hawthorn (Ed.), The Standard of Living, The Tanner Lectures (Clare Hall, Cambridge, 1985), Cambridge University Press, New York.

Sen, A.K. (1992) Inequality Reexamined, Harvard University Press, Cambridge, MA.

Sen, A.K. (1999) Development as Freedom, Alfred A. Knoff, New York.

Silver, H. (1994) 'Social exclusion and social solidarity: three paradigms', International Labor Review, 133(5-6).

Silver, H. (1995) 'Reconceptualizing social disadvantage: three paradigms of social exclusion', in G. Rodgers, C. Gore and J.B. Figueiredo (Eds), Social Exclusion: Rhetoric, Reality, Responses, International Institute for Labour Studies, Geneva, pp. 531-578.

Sparkes, J. and Glennerster, H. (2002) 'Preventing social exclusion: education's contribution', in T. Burchardt, J. Le Grand and D B. Piachaud (Eds), Understanding Social Exclusion, Oxford University Press, London.

Strobel, P. (1996) 'From poverty to exclusion: a wage-earning society to a society of human rights', International Social Science Journal, 48(148), pp. 173-189.

Taylor, P. (1999) 'Democratizing cities: habitat's global campaign on urban governance', Habitat Debate, 5(4), pp. 1-5.

Tsui, K. (2002) 'Multidimensional poverty indices', Social Choice and Welfare, 19(1), pp. 69-93.

UNDP (2000a) Overcoming Human Poverty: United Nations Development Programme Poverty Report 2000, United Nations Development Programme, New York.

UNDP (2000b) Human Development Report 2000, Oxford University Press, New York.

UNDP (2002) Human Development Report 2002, Oxford University Press, New York.

UNDP/Nepal (1998) Nepal: Human Development Report 1998, UNDP/Nepal, Kathmandu.

UNDP/Nepal (2002) Nepal Human Development Report 2001, UNDP/Nepal, Kathmandu.

Wagle, U. (2002) 'Rethinking poverty: definition and measurement', International Social Science Journal, 54(171), pp. 155-165.

Wagle, U. (2004a) 'Poverty in Kathmandu: what do subjective and objective economic welfare concepts suggest?', presented at Eastern Economic Association Conference, 2022 February, Washington, DC.

Wagle, U. (2004b) 'A multidimensional approach to poverty: economic well-being, capability, and social inclusion in the city of Kathmandu', Ph.D. Thesis, University of Massachusetts Boston, Boston.

Wagle, U. (2004c) 'Civic engagement and political participation in Kathmandu: an empirical analysis of the structural relationships', presented at American Political Science Association Conference, 2-5 September, Chicago, IL.

Wagle, U. (2005) 'Constituency crisis: the political stalemate' (op-ed piece), The Kathmandu Post, 21 and 22 May.

Wagle, U. (Forthcoming) 'The estimates and characteristics of poverty in Kathmandu: what do three measurement standards suggest?', Social Science Journal, 43(4). 


\section{U. Wagle}

Weiss, L. (1999) 'Single women in Nepal: familial support, familial neglect', Journal of Comparative Family Studies, 30(2), pp. 243-255.

White, G. (1997) 'Civil society, social exclusion and poverty alleviation', in C. Gore and J. Figueiredo (Eds), Social Exclusion and Anti-Poverty Policy: A Debate, Research Series 110, International Institute for Labour Studies, Geneva.

World Bank (1991) Nepal: Poverty and Incomes: A Joint Study, The World Bank, Washington, DC.

World Bank (2001) World Development Report 2000/2001, Oxford University Press, New York.

World Bank (2003a) World Development Report 2003, Oxford University Press, New York. World Bank (2003b) World Development Report 2004, Oxford University Press, New York.

\section{Appendix}

\section{Description of Variables}

\begin{tabular}{|c|c|c|c|}
\hline Variable & Type & Values & Definition \\
\hline \multicolumn{4}{|c|}{ Latent Concepts/Dimensions } \\
\hline $\begin{array}{l}\text { Subjective Economic } \\
\text { Well-being }\end{array}$ & Continuous & -2.2 to 1.8 & $\begin{array}{l}\text { State of economic well-being as perceived } \\
\text { by householders }\end{array}$ \\
\hline $\begin{array}{l}\text { Objective Economic } \\
\text { Well-being }\end{array}$ & Continuous & -0.6 to 2.2 & Objective state of economic well-being \\
\hline Economic Well-being & Continuous & -1.9 to 1.7 & $\begin{array}{l}\text { Overall state of economic well-being } \\
\text { indicated by subjective and objective } \\
\text { states of well-being }\end{array}$ \\
\hline Capability & Continuous & -0.5 to 0.4 & Overall capability of households \\
\hline Economic Inclusion & Continuous & -2.3 to 1.3 & $\begin{array}{l}\text { Extent of integration/disintegration of } \\
\text { households in the labor market and the } \\
\text { economy }\end{array}$ \\
\hline Political Inclusion & Continuous & -1.1 to 1.3 & $\begin{array}{l}\text { Extent of integration/disintegration in the } \\
\text { larger political systems }\end{array}$ \\
\hline Civic/Cultural Inclusion & Continuous & -2.1 to 2.5 & $\begin{array}{l}\text { Extent of integration/disintegration in the } \\
\text { community or larger society }\end{array}$ \\
\hline Social Inclusion & Varies & Varies & $\begin{array}{l}\text { Overall state of inclusion in society as } \\
\text { indicated by economic, political, and civic/ } \\
\text { cultural inclusion }\end{array}$ \\
\hline Poverty & Varies & Varies & $\begin{array}{l}\text { Overall state of well-being indicated by } \\
\text { economic well-being, capability, and social } \\
\text { inclusion }\end{array}$ \\
\hline \multicolumn{4}{|c|}{ Observed Indicator variables } \\
\hline Income & Continuous & $3 \mathrm{k}$ to $660 \mathrm{k}$ & $\begin{array}{l}\text { Per capita annual income in the hosuehold } \\
\text { (Measured in Nepali Rupees) }\end{array}$ \\
\hline Consumption & Continuous & $4 \mathrm{k}$ to $179 \mathrm{k}$ & $\begin{array}{l}\text { Per capita annual consumption expenses on } \\
\text { all food and nonfood items (Measured in } \\
\text { Nepali Rupees) }\end{array}$ \\
\hline $\begin{array}{l}\text { Adequacy of income } \\
\text { for food }\end{array}$ & Ordered & 1 to 5 & $\begin{array}{l}\text { Household income is adequate to cover food } \\
\text { expenses (strongly disagree, disagree, no } \\
\text { opinion, agree, strongly agree) }\end{array}$ \\
\hline $\begin{array}{l}\text { Adequacy of income } \\
\text { for other expenses }\end{array}$ & Ordered & 1 to 5 & $\begin{array}{l}\text { Income adequate to cover non-food } \\
\text { expenses (strongly disagree, disagree, no } \\
\text { opinion, agree, strongly agree) }\end{array}$ \\
\hline $\begin{array}{l}\text { Potential increase in } \\
\text { food expenses }\end{array}$ & Ordered & 1 to 3 & $\begin{array}{l}\text { Potential increase in food expenses due to } \\
\text { hypothetical increase in income (increase } \\
\text { a lot, increase somewhat, no change) }\end{array}$ \\
\hline
\end{tabular}




\section{(Continued.)}

\begin{tabular}{|c|c|c|c|}
\hline Variable & Type & Values & Definition \\
\hline $\begin{array}{l}\text { Potential increase } \\
\text { in non-food expenses }\end{array}$ & Ordered & 1 to 3 & $\begin{array}{l}\text { Potential increase in non-food expenses due } \\
\text { to hypothetical increase in income (increase } \\
\text { a lot, increase somewhat, no change) }\end{array}$ \\
\hline $\begin{array}{l}\text { Mean educational } \\
\text { attainment }\end{array}$ & Continuous & 0 to 18 & $\begin{array}{l}\text { Average educational attainment for adults in } \\
\text { number of years of schooling }\end{array}$ \\
\hline $\begin{array}{l}\text { Overall nutrition in } \\
\text { the household }\end{array}$ & Ordered & 1 to 5 & $\begin{array}{l}\text { Perception that hosuehold members have } \\
\text { adequate nutrition (strongly disagree, } \\
\text { disagree, no opinion, agree, strongly agree) }\end{array}$ \\
\hline $\begin{array}{l}\text { Equality in educational } \\
\text { opportunities }\end{array}$ & Ordered & 1 to 5 & $\begin{array}{l}\text { Perception of equality of educational } \\
\text { opportunities between males and females } \\
\text { in the household (strongly disagree, } \\
\text { disagree, no opinion, agree, strongly agree) }\end{array}$ \\
\hline $\begin{array}{l}\text { Householder's } \\
\text { educational attainment }\end{array}$ & Continuous & 0 to 22 & $\begin{array}{l}\text { Number of years of schooling for } \\
\text { hosueholders }\end{array}$ \\
\hline $\begin{array}{l}\text { Vocational or } \\
\text { professional training }\end{array}$ & Continuous & 0 to 37 & $\begin{array}{l}\text { Average number of vocational training } \\
\text { acquired by adults }\end{array}$ \\
\hline Adult morbidity & Continuous & 0 to 547 & Per capita sick days for adults in the last year \\
\hline Child morbidity & Continuous & 0 to 227 & Per capita sick days for children in the last year \\
\hline $\begin{array}{l}\text { Overall health in } \\
\text { the household }\end{array}$ & Ordered & 1 to 5 & $\begin{array}{l}\text { Perception that health status of household } \\
\text { members is good (strongly disagree, dis } \\
\text { agree, no opinion, agree, strongly agree) }\end{array}$ \\
\hline $\begin{array}{l}\text { Relative importance } \\
\text { of sons vs. daughters }\end{array}$ & Ordered & 1 to 5 & $\begin{array}{l}\text { Perception that sons are more important } \\
\text { than daughters (strongly disagree, } \\
\text { disagree, no opinion, agree, strongly agree) }\end{array}$ \\
\hline $\begin{array}{l}\text { Gender equality in } \\
\text { household decision }\end{array}$ & Ordered & 1 to 5 & $\begin{array}{l}\text { Perception of men and women to have equal } \\
\text { say in household decisions (strongly } \\
\text { disagree, disagree, no opinion, agree, } \\
\text { strongly making agree) }\end{array}$ \\
\hline $\begin{array}{l}\text { Caste discrimination } \\
\text { in the neighborhood }\end{array}$ & Ordered & 1 to 5 & $\begin{array}{l}\text { Perception of caste discrimination in the } \\
\text { neighborhood (strongly disagree, } \\
\text { disagree, no opinion, agree, strongly agree) }\end{array}$ \\
\hline $\begin{array}{l}\text { Ethnic discrimination in } \\
\text { the neighborhood }\end{array}$ & & & $\begin{array}{l}\text { Perception of ethnic discrimination in the } \\
\text { neighborhood (strongly disagree, } \\
\text { disagree, no opinion, agree, strongly agree) }\end{array}$ \\
\hline $\begin{array}{l}\text { Access to financial } \\
\text { resources }\end{array}$ & Ordered & 1 to 3 & $\begin{array}{l}\text { Type of access to financial resources } \\
\text { (none, individual, institutional) }\end{array}$ \\
\hline $\begin{array}{l}\text { \% unemployed in } \\
\text { household }\end{array}$ & Continuous & 0 and 100 & $\%$ unemployed among adults in household \\
\hline $\begin{array}{l}\text { Householder } \\
\text { occupation }\end{array}$ & Categorical & 0 and 1 & $\begin{array}{l}\text { Householders occupation: executive or } \\
\text { professional; armed forces, farming, labor, } \\
\text { or machine operation; sales; } \\
\text { administrative support; craft }\end{array}$ \\
\hline Employment industry & Continuous & 0 to 100 & $\begin{array}{l}\text { Percent employed among adults in } \\
\text { government agencies; NGOs; public } \\
\text { enterprises; private companies; private } \\
\text { registered businesses; private unregistered } \\
\text { businesses }\end{array}$ \\
\hline Self-employment status & Continuous & 0 to 100 & $\begin{array}{l}\text { Percent self-employed among adults with } \\
\text { registered businesses and with } \\
\text { unregistered businesses }\end{array}$ \\
\hline $\begin{array}{l}\text { Caste discrimination } \\
\text { in the labor market }\end{array}$ & Ordered & 1 to 5 & $\begin{array}{l}\text { Perception of caste discrimination in the } \\
\text { labor market (strongly disagree, disagree, } \\
\text { no opinion, agree, strongly agree) }\end{array}$ \\
\hline
\end{tabular}


(Continued.)

\begin{tabular}{|c|c|c|c|}
\hline Variable & Type & Values & Definition \\
\hline $\begin{array}{l}\text { Ethnic discrimination } \\
\text { in the labor market }\end{array}$ & & & $\begin{array}{l}\text { Perception of ethnic discrimination in the } \\
\text { labor market (strongly disagree, disagree, } \\
\text { no opinion, agree, strongly agree) }\end{array}$ \\
\hline $\begin{array}{l}\text { Citizenship card } \\
\text { holding }\end{array}$ & Continuous & 0 to 100 & Percent adult members without citizenship card \\
\hline Voter registration & Continuous & 0 to 100 & $\begin{array}{l}\text { Percent adult members registered to vote in } \\
\text { Kathmandu }\end{array}$ \\
\hline Voting frequency & Continuous & 0.3 to 3 & $\begin{array}{l}\text { Average voting frequency for all adults } \\
\text { (based on incividual frequencies: never, } \\
\text { sometimes, always) }\end{array}$ \\
\hline $\begin{array}{l}\text { Participation in } \\
\text { partisan activities }\end{array}$ & Ordered & 1 to 3 & $\begin{array}{l}\text { Frequency of participation in political } \\
\text { meetings, rallies, and demonstration } \\
\text { (never, sometimes, often) }\end{array}$ \\
\hline $\begin{array}{l}\text { Informal talk about } \\
\text { policies }\end{array}$ & Ordered & 1 to 3 & $\begin{array}{l}\text { Freuency of informal conversations about } \\
\text { policy issues held with other families or } \\
\text { friends (Never, sometimes, often) }\end{array}$ \\
\hline $\begin{array}{l}\text { Contacts from political } \\
\text { leaders }\end{array}$ & Ordered & 1 to 3 & $\begin{array}{l}\text { Frequency of visits, calls, or other contacts } \\
\text { from political leaders (never, sometimes, } \\
\text { often) }\end{array}$ \\
\hline $\begin{array}{l}\text { Communicate with } \\
\text { political leaders }\end{array}$ & Ordered & 1 to 3 & $\begin{array}{l}\text { Frequency of verbal or written } \\
\text { communication with political leaders } \\
\text { (never, sometimes, often) }\end{array}$ \\
\hline $\begin{array}{l}\text { Headship of political } \\
\text { positions }\end{array}$ & Continuous & 0 to 1.33 & $\begin{array}{l}\text { Average headship of political positions held } \\
\text { by adults }\end{array}$ \\
\hline $\begin{array}{l}\text { Motive of political } \\
\text { leaders }\end{array}$ & Ordered & 1 to 5 & $\begin{array}{l}\text { Perception that political leaders are there to } \\
\text { help people (strongly disagree, disagree, } \\
\text { no opinion, agree, strongly agree) }\end{array}$ \\
\hline $\begin{array}{l}\text { Organizational } \\
\text { memberships }\end{array}$ & Continuous & 0 to 6 & $\begin{array}{l}\text { Number of memberships to registered or } \\
\text { unregistered organizations or groups in } \\
\text { per capita terms for adults }\end{array}$ \\
\hline $\begin{array}{l}\text { Participation in social } \\
\text { activities }\end{array}$ & Ordered & 1 to 3 & $\begin{array}{l}\text { Frequency of participation in social or } \\
\text { cultural activities that are organized by } \\
\text { inviting relatives and friends (never, } \\
\text { sometimes, often) }\end{array}$ \\
\hline $\begin{array}{l}\text { Participation in joint } \\
\text { activities }\end{array}$ & Ordered & 1 to 3 & $\begin{array}{l}\text { Frequency of participation in activities } \\
\text { jointly carried out with other relatives or } \\
\text { friends (never, sometimes, often) }\end{array}$ \\
\hline $\begin{array}{l}\text { Social networks and } \\
\text { ties }\end{array}$ & Ordered & 1 to 5 & $\begin{array}{l}\text { Extent of social networks and ties as } \\
\text { indicated by agreement over the ability to } \\
\text { get jobs when needed (strongly disagree, } \\
\text { disagree, no opinion, agree, strongly agree) }\end{array}$ \\
\hline Family contacts & Continuous & 0 to 200 & $\begin{array}{l}\text { Number of families coming into contact in } \\
\text { special ocassions }\end{array}$ \\
\hline $\begin{array}{l}\text { Children's access to } \\
\text { friends }\end{array}$ & Ordered & 1 to 5 & $\begin{array}{l}\text { Perception of children's access to friends in } \\
\text { the neighborhood to get along and play } \\
\text { with (strongly disagree, disagree, no } \\
\text { opinion, agree, strongly agree) }\end{array}$ \\
\hline $\begin{array}{l}\text { Access to noneconomic } \\
\text { help }\end{array}$ & Ordered & 1 to 5 & $\begin{array}{l}\text { Perception of access to noneconomic help in } \\
\text { the neighborhood when needed (strongly } \\
\text { disagree, disagree, no opinion, agree, } \\
\text { strongly agree) }\end{array}$ \\
\hline
\end{tabular}

